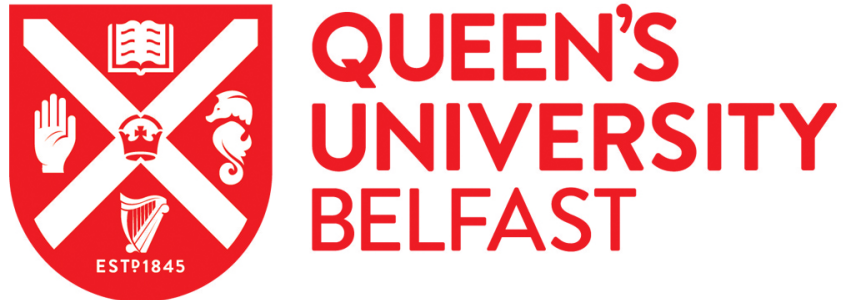

\section{Risk of Death from Pneumocystis jirovecii after Curative-intent Radiotherapy for Lung Cancer}

McAleese, J., Mooney, L., Walls, G. M., Eakin, R. L., Harney, J., \& Hanna, G. G. (2018). Risk of Death from Pneumocystis jirovecii after Curative-intent Radiotherapy for Lung Cancer. Clinical Oncology, 30(12), e81-e82. https://doi.org/10.1016/j.clon.2018.08.006

\section{Published in: \\ Clinical Oncology}

\section{Document Version:}

Peer reviewed version

Queen's University Belfast - Research Portal:

Link to publication record in Queen's University Belfast Research Portal

\section{Publisher rights}

(c) 2018 The Royal College of Radiologists. Published by Elsevier Ltd. All rights reserved.

This manuscript version is made available under the CC-BY-NC-ND 4.0 license http://creativecommons.org/licenses/by-nc-nd/4.0/,which permits distribution and reproduction for noncommercial purposes, provided the author and source are cited

\section{General rights}

Copyright for the publications made accessible via the Queen's University Belfast Research Portal is retained by the author(s) and / or other copyright owners and it is a condition of accessing these publications that users recognise and abide by the legal requirements associated with these rights.

Take down policy

The Research Portal is Queen's institutional repository that provides access to Queen's research output. Every effort has been made to ensure that content in the Research Portal does not infringe any person's rights, or applicable UK laws. If you discover content in the Research Portal that you believe breaches copyright or violates any law, please contact openaccess@qub.ac.uk. 


\title{
Risk of death from Pneumocystis jirovecii after curative-intent radiotherapy for lung cancer
}

Jonathan McAleese ${ }^{a, b}$, Laura Mooney ${ }^{a}$, Gerard M. Walls ${ }^{a, b}$, Ruth Eakin ${ }^{a}$, Jacqueline Harney ${ }^{a}$, Gerard G. Hanna $a^{\mathrm{a}, \mathrm{b}}$.

${ }^{a}$ Cancer Centre, Belfast City Hospital, Northern Ireland.

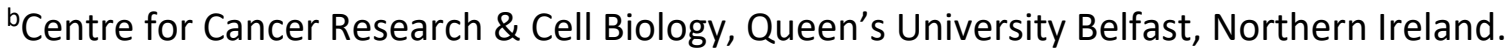

\begin{abstract}
Background

Radical radiotherapy is given in the curative setting for patients with non-small cell lung cancer (NSCLC) and small cell lung cancer (SCLC). Pneumocystis jirovecii pneumonia (PJP) in HIV-negative patients carries a high mortality. We determined the risk of death from PJP in a cohort of patients treated with radical radiotherapy.
\end{abstract}

\section{Methods}

Case records for all patients treated with radical radiotherapy for NSCLC and SCLC in Northern Ireland, between Jan 2011 and Dec 2016 inclusive, were examined to determine the cause of death. Survival was estimated using the Kaplan Meier method.

\section{Results}

683 patients were studied. At a median follow up of 15 months, 379 patients (55\%) had died. The cause of death was determined in all but 5 patients. 6 patients died with progressive pneumonia and quantitative PCR confirmation of PJP infection. A further 8 patients died of progressive pneumonia with bilateral radiological changes. Whilst no serological or microbiological confirmation was available they met the criteria for possible PJP infection. All patients had received corticosteroids within the preceding 3 months; 13 had lymphopenia for at least a month prior to diagnosis. The actuarial risk of death from definite or possible PJP was $2.6 \%$ at 2 years ( $95 \% \mathrm{Cl} 1.2 \%$ to $4.0 \%$ ).

\section{Conclusions}

We conclude that there is a clinically significant risk of death from PJP in patients treated with radiotherapy. An association with prior steroid use and prolonged lymphopenia is noted. We advocate the use of chemoprophylaxis in patients receiving steroids who have had radical radiotherapy. 


\section{Manuscript}

\section{Background}

Pneumocystis jirovecii pneumonia (PJP) is a potentially life threatening infection, with symptoms which include non-productive cough, dyspnoea and low grade pyrexia. The diagnosis of PJP has risen by an average of $7 \%$ per year from $2000-2010$ in non-HIV patients [1]. Risk factors for PJP include prolonged lymphopenia, chemotherapy, radiotherapy and steroid use [2]. In non-HIV patients infection carries an average in-hospital mortality rate of 50\% [3]. Identification and prophylactic treatment of high risk populations is therefore essential [4], along with a high index of suspicion for diagnosis.

Lung cancer is the $3^{\text {rd }}$ most common cancer in the UK [5], and remains the most common cause of cancer death. Patients often have multiple co-morbidities, including chronic lung diseases, making them unsuitable for radical surgery [6]. After surgery, radical radiotherapy is the second most commonly used curative treatment for lung cancer, with potential cure rates of 20-40\% [7]. Efforts to improve outcomes through altered fractionation and combining radiotherapy with chemotherapy have improved survival [8-10].

The incidence of PJP in the general lung cancer population has been reported as 2.6 cases per 100,000 person-years [11]. However patients receiving radical radiotherapy treatment for lung cancer may be exposed to several risk factors for PJP and may be at higher risk. We aimed to determine the risk of death from PJP in our patients treated with radical radiotherapy. 


\section{Methods}

Case records for all patients treated with radical radiotherapy for non-small cell lung cancer (NSCLC) and small cell lung cancer (SCLC) in Northern Ireland, between Jan 2011 and Dec 2016 inclusive, were examined to determine the cause of death. All radiation courses were delivered with threedimensional conformal, volumetric arc therapy (VMAT) or intensity-modulated radiotherapy (IMRT) techniques. Respiratory motion was compensated by a four dimensional computed tomography (4DCT) scan to create an internal target volume (ITV). The fractionations used to treat NSCLC were $55 \mathrm{~Gy} / 20 \#$ over 4 weeks or $66 \mathrm{~Gy} / 33 \#$ over 6 and a half weeks. Patients with SCLC were treated with either $40 \mathrm{~Gy} / 15 \#$ over 3 weeks, 45Gy/30\# over 3 weeks or $50 \mathrm{~Gy} / 25 \#$ over 5 weeks. Chemotherapy was used for patients with advanced disease, in line with national guidelines [12]. AJCC $7^{\text {th }}$ edition was used for staging [13]. Survival was taken from the start of radiotherapy, or the start of primary chemotherapy if a sequential chemoradiation strategy was used. Actuarial survival was calculated using MEDCALC version 9.3.9.0 and using the Kaplan Meier method. PJP was considered proven if microbiological or quantitative polymerase chain reaction (qPCR) tests were positive in the presence of clinical and radiological signs of progressive pneumonia [14] (table 1). PJP was considered possible when there were clinical signs of progressive pneumonia and either compatible radiological signs or complete resolution after PJP treatment but with absence of microbiological or qPCR confirmation. Lymphopenia was defined as lower than the hospital reference range $\left(<1 \times 10^{9}\right.$ cell per litre $)$.

Table 1: Definitions for PJP diagnoses

\begin{tabular}{|l|l|}
\hline Definite PJP & $\begin{array}{l}\text { Clinical signs of progressive pneumonia } \\
\text { Ground glass opacity on Computed Tomography (CT) imaging } \\
\text { Microscopically identified }\end{array}$ \\
\hline Probable PJP & $\begin{array}{l}\text { Clinical signs of progressive pneumonia } \\
\text { Ground glass opacity on CT imaging } \\
\text { Complete resolution of symptoms after PCP treatment } \\
\text { PJP not microscopically identified }\end{array}$ \\
\hline Possible PJP & $\begin{array}{l}\text { Clinical signs of progressive pneumonia } \\
\text { PJP not microscopically identified AND } \\
\text { Compatible radiological signs OR } \\
\text { Complete resolution of symptoms post PCP treatment }\end{array}$ \\
\hline Other diagnosis & None of the above criteria \\
\hline
\end{tabular}




\section{Results}

Six hundred and ninety courses of radical radiotherapy for lung cancer were delivered between 2011 and 2016 (figure 1). Seven patients were re-irradiated with radical intent within the time period. Only the first course was used for analysis, such that 683 patient records were included.

Figure 1: CONSORT diagram

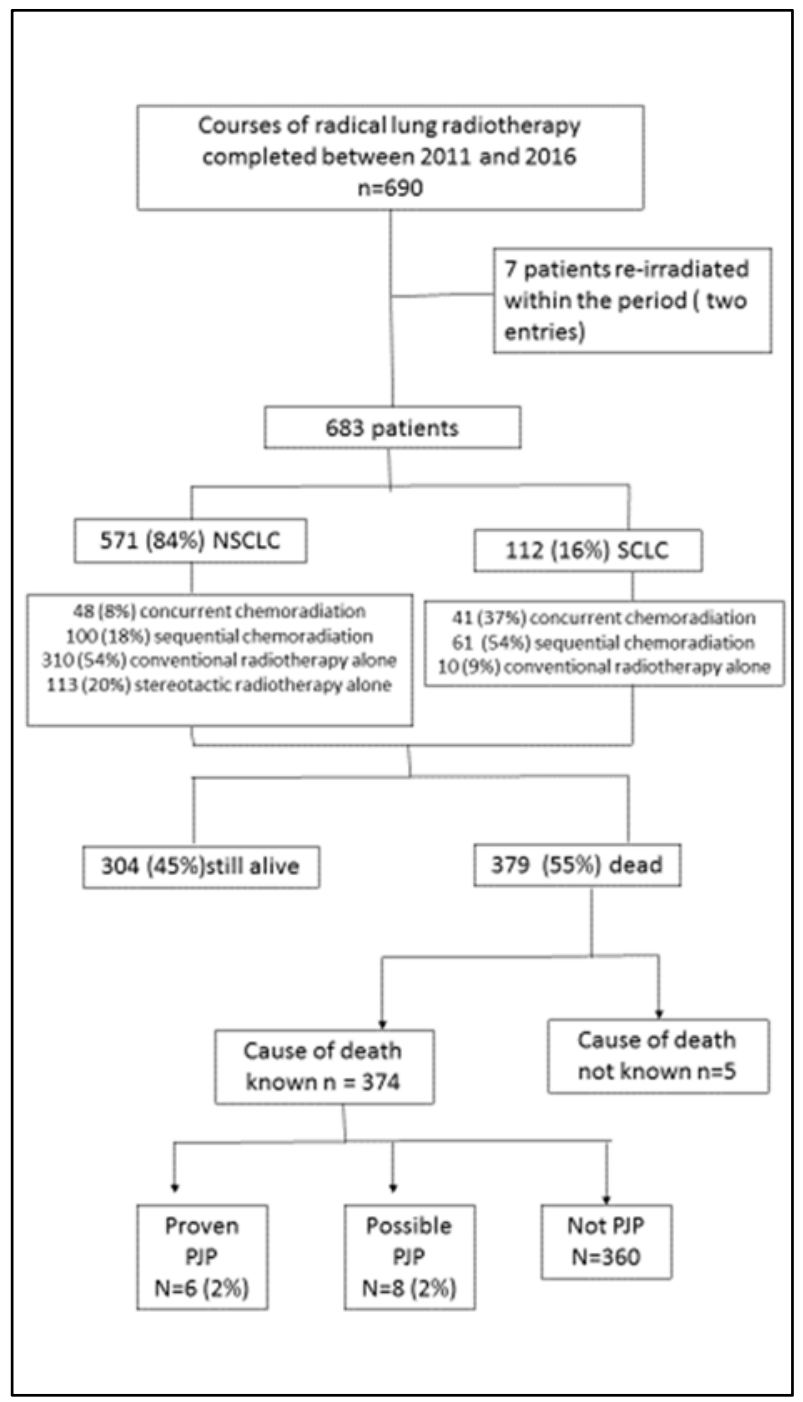

The average age was 70 years (table 2 ). Fifty six (56\%) were male. Forty-one percent (41\%) were of poor performance status (PS 2 plus). Sixteen percent of patients were treated for SCLC and $84 \%$ for non-small cell lung cancer NSCLC, of whom the predominant subtype was squamous carcinoma. $20 \%$ 
of all patients had no histological confirmation of lung cancer and were diagnosed based on radiological features. Chemotherapy was given along with radiotherapy to 250 (37\%) patients.

Table 2: Demographics of the study population

\begin{tabular}{|c|c|}
\hline Number of patients & 683 \\
\hline Average age (+/- SD) & 70 (+/-9 years) \\
\hline Gender & $56 \%$ male / $44 \%$ female \\
\hline $\begin{array}{l}\text { WHO Performance Status (PS) } \\
0 \\
1 \\
\geq 2 \\
\text { Unknown }\end{array}$ & $\begin{array}{l}12 \% \\
45 \% \\
41 \% \\
2 \%\end{array}$ \\
\hline Mean \%FEV1 (range) & $81 \%$ (31\%-179\%) \\
\hline $\begin{array}{ll}\text { TNM Stage } & \text { I (NSCLC) } \\
& \text { II (NSCLC) } \\
& \text { IIIA (NSCLC) } \\
& \text { IIIB (NSCLC) } \\
\text { IV, } 2 \text { separate primaries (NSCLC) } \\
\text { Limited Stage disease (SCLC) } \\
\text { missing }\end{array}$ & \begin{tabular}{l|}
$33 \%$ \\
$12 \%$ \\
$30 \%$ \\
$8 \%$ \\
$1 \%$ \\
$16 \%$ \\
$0 \%$
\end{tabular} \\
\hline $\begin{array}{r}\text { Pathological Subtype } \\
\text { Adenocarcinoma } \\
\text { Squamous carcinoma } \\
\text { Other } \\
\text { No histological diagnosis/Unknown } \\
\text { SCLC }\end{array}$ & $\begin{array}{l}25 \% \\
33 \% \\
6 \% \\
20 \% \\
16 \%\end{array}$ \\
\hline $\begin{array}{l}\text { Treatment Paradigm } \\
\text { NSCLC concurrent chemoradiation } \\
\text { NSCLC sequential chemoradiation } \\
\text { NSCLC Stereotactic radiotherapy (SABR) } \\
\text { NSCLC non- SABR radiotherapy alone } \\
\text { SCLC concurrent chemoradiation } \\
\text { SCLC sequential chemoradiation } \\
\text { SCLC non-SABR radiotherapy alone }\end{array}$ & $\begin{array}{l}7 \% \\
45 \% \\
15 \% \\
17 \% \\
6 \% \\
9 \% \\
1 \%\end{array}$ \\
\hline
\end{tabular}

Three hundred and four (45\%) out of the 683 patients were still alive with a median follow up of 16 months. Of the 379 who had died, the cause of death was not able to be determined in 5 (1\%) patients. These patients had died unexpectedly in the community without obvious evidence of progression or obvious cause of death in the case records. Cause of death was determined in 374 patients (figure 2). Most patients (244,64\%) died from progressive lung cancer. Forty patients (11\%) 
died from a chest infection which did not meet the criteria for possible PJP. Twenty-seven patients (7\%) died from vascular causes such as myocardial infarct, heart failure or ruptured aortic aneurysm. Five patients (1\%) died from radiotherapy fibrosis.

Figure 2: Cause of death

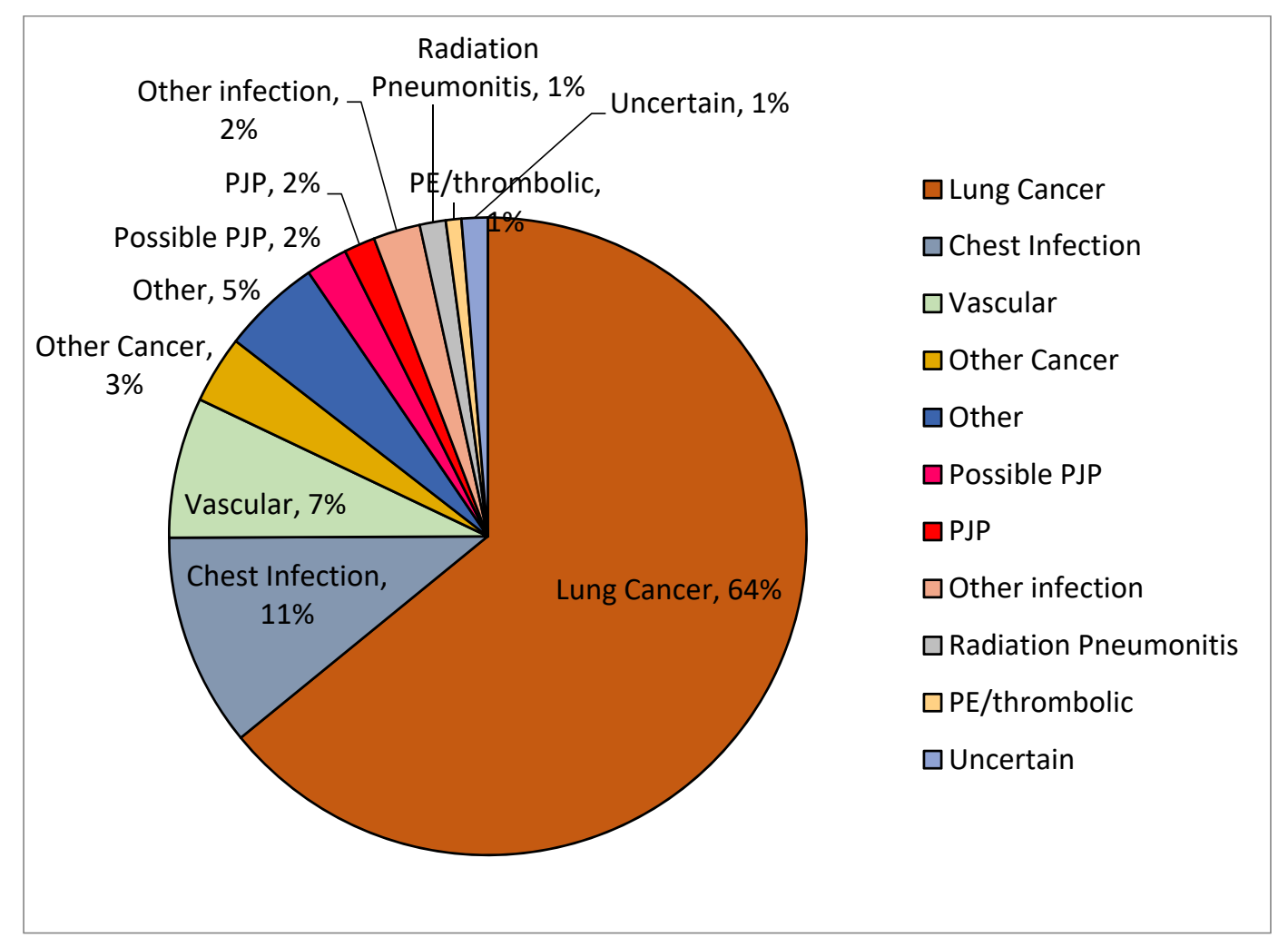

6 patients died of PJP confirmed by qPCR in the presence of progressive pneumonia and computed tomography (CT) changes. 8 died from progressive pneumonia with progressive bilateral changes on radiology, but without qPCR or microbiology having been sent. These patients met the criteria for possible PJP (table 1). Patients died from PCP at a median of 3 months (range 0.2 to 15 months) from the end of their radiation course. Three patients $(21 \%)$ had been treated with chemotherapy in addition to their radiotherapy. All 6 patients with definite PJP and 7 out of the 8 patients with possible PJP were receiving steroids when they were diagnosed with pneumonia (table 3 ). The other patient had received steroids within the previous 3 months. All but one patient had lymphopenia for 1 month prior to diagnosis of PJP or possible PJP. The actuarial rate of death from definite PJP or 
possible PJP was $2.6 \%$ at 2 years $(95 \% \mathrm{Cl} 1.2 \%$ to $4.0 \%)$. The rate of death from definite PJP only was $1.2 \%(95 \% \mathrm{Cl} 0.2 \%$ to $2.2 \%)$.

Table 3: Characteristics of patients diagnosed with PJP

\begin{tabular}{|c|c|c|c|c|c|c|c|c|c|c|c|c|}
\hline & PJP & $\begin{array}{l}\text { Age } \\
\text { (years) }\end{array}$ & Gender & Stage & Dose & $\begin{array}{l}\text { Lung volume } \\
\text { receiving } \\
\geq 20 G y\end{array}$ & $\begin{array}{l}\text { Time from } \\
\text { RTX } \\
\text { (months) }\end{array}$ & Chemo & $\begin{array}{l}\text { Lymphopenia } \\
\text { for } \geq 1 \text { month }\end{array}$ & $\begin{array}{l}\text { Lymphocyte } \\
\text { on } \\
\text { admission }\end{array}$ & $\begin{array}{l}\text { Steroids } \\
\text { within last } 3 \\
\text { months }\end{array}$ & Radiology \\
\hline 1 & Definite & 67 years & $\mathrm{M}$ & IIIA & 55Gy/20\# & $30 \%$ & 3.3 & no & yes & $0.3 \times 10^{9} / 1$ & $\begin{array}{l}\text { Receiving up } \\
\text { to infection }\end{array}$ & CT- bilateral nodular \\
\hline 2 & Definite & 71 years & $\mathrm{F}$ & IIIB & 55Gy/20\# & $36 \%$ & 0.2 & no & yes & $0.2 \times 10^{9} / I$ & $\begin{array}{l}\text { Receiving up } \\
\text { to infection }\end{array}$ & $\begin{array}{l}\text { CT- bilateral ground } \\
\text { glass }\end{array}$ \\
\hline 3 & Definite & 74 years & $\mathrm{F}$ & IIIA & 55Gy/20\# & $31 \%$ & 6.4 & concurrent & yes & $0.24 \times 10^{9} / 1$ & $\begin{array}{l}\text { Receiving up } \\
\text { to infection }\end{array}$ & $\begin{array}{l}\text { CT- bilateral ground } \\
\text { glass }\end{array}$ \\
\hline 4 & Definite & 71 years & $M$ & IIA & $55 G y / 20 \#$ & $20 \%$ & 15.2 & no & yes & $0.4 \times 10^{9} / 1$ & $\begin{array}{l}\text { Receiving up } \\
\text { to infection }\end{array}$ & $\begin{array}{l}\text { CT- bilateral ground } \\
\text { glass }\end{array}$ \\
\hline 5 & Definite & 71 years & $\mathrm{M}$ & IIIA & 55Gy/20\# & $31 \%$ & 3.8 & no & yes & $0.56 \times 10^{9} / 1$ & $\begin{array}{l}\text { Receiving up } \\
\text { to infection }\end{array}$ & $\begin{array}{l}\text { CT- bilateral ground } \\
\text { glass }\end{array}$ \\
\hline 6 & Definite & 62 years & M & IB & 55Gy/20\# & $31 \%$ & 1.4 & no & yes & $0.4 \times 10^{9} / 1$ & $\begin{array}{l}\text { Receiving up } \\
\text { to infection }\end{array}$ & $\begin{array}{l}\text { CT- bilateral ground } \\
\text { glass }\end{array}$ \\
\hline 7 & Possible & 84 years & $M$ & IIA & 55Gy/20\# & $18 \%$ & 2.2 & no & yes & $0.41 \times 10^{9} / /$ & $\begin{array}{l}\text { Receiving up } \\
\text { to infection }\end{array}$ & $\begin{array}{l}\text { CT- bilateral ground } \\
\text { glass }\end{array}$ \\
\hline 8 & Possible & 81 years & $\mathrm{F}$ & IIIA & 55Gy/20\# & $25 \%$ & 3.0 & no & yes & $0.57 \times 10^{9} / /$ & $\begin{array}{l}\text { Receiving up } \\
\text { to infection }\end{array}$ & $\begin{array}{l}\text { CT- bilateral } \\
\text { interstitial thickening }\end{array}$ \\
\hline 9 & Possible & 69 years & $M$ & IIIB & 55Gy/20\# & $21 \%$ & 1.0 & sequential & yes & $0.6 \times 10^{9} / 1$ & $\begin{array}{l}\text { Within prior } 3 \\
\text { months }\end{array}$ & $\begin{array}{l}\text { CXR - bilateral } \\
\text { alveolar }\end{array}$ \\
\hline 10 & Possible & 81 years & $\mathrm{M}$ & IIIA & 66Gy/33\# & $35 \%$ & 2.8 & no & no & $0.21 \times 10^{9} / 1$ & $\begin{array}{l}\text { Receiving up } \\
\text { to infection }\end{array}$ & $\begin{array}{l}\text { CXR-bilateral } \\
\text { alveolar }\end{array}$ \\
\hline 11 & Possible & 71 years & $\mathrm{F}$ & IIIA & 55Gy/20\# & $34 \%$ & 3.4 & no & yes & $0.3 \times 10^{9} / 1$ & $\begin{array}{l}\text { Receiving up } \\
\text { to infection }\end{array}$ & $\begin{array}{l}\text { CXR - bilateral } \\
\text { alveolar }\end{array}$ \\
\hline 12 & Possible & 65 years & $\mathrm{M}$ & IV & 55Gy/20\# & $31 \%$ & 1.3 & no & yes & $0.8 \times 10^{9} / 1$ & $\begin{array}{l}\text { Receiving up } \\
\text { to infection }\end{array}$ & $\begin{array}{l}\text { CXR-bilateral } \\
\text { alveolar }\end{array}$ \\
\hline 13 & Possible & 75 years & $\mathrm{F}$ & LD & $50 \mathrm{~Gy} / 25 \#$ & $25 \%$ & 1.7 & sequential & yes & $0.46 \times 10^{9} / 1$ & Receiving up & CT- bilateral ground \\
\hline
\end{tabular}

Figure 3: Risk of Death from PJP with 95\% confidence intervals

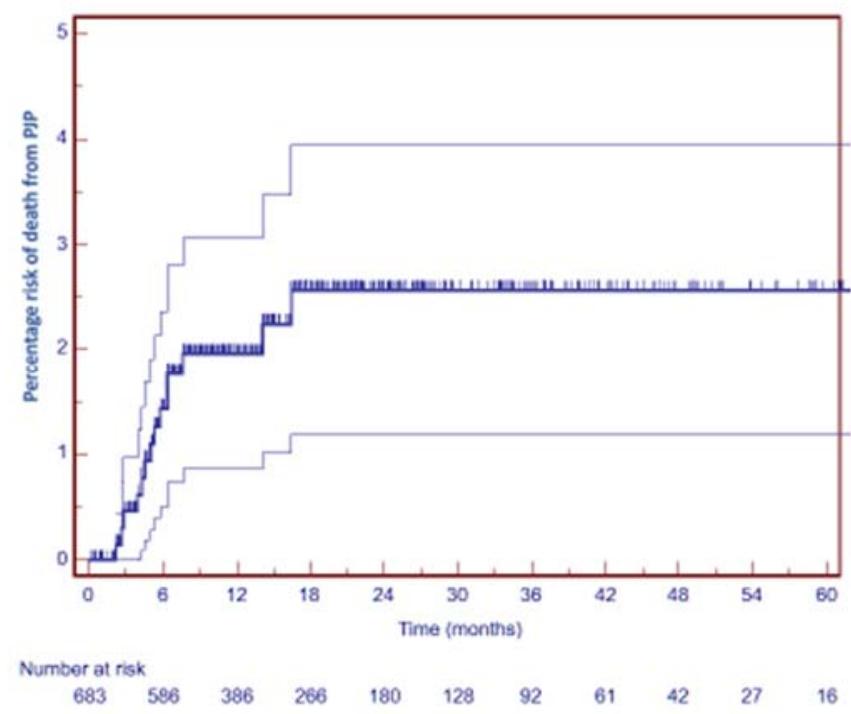




\section{Discussion}

The demographic characteristics of patients in our study are comparable to a national UK audit [15]. Survival outcomes for our patients have been previously reported [16] and are similar to other centres in the UK [17] and Europe [16]. We suggest that this study is representative of patients selected for curative-intent radiotherapy, and as such we propose that the findings are generalizable to all such treated patients.

Many studies have used the microscopic detection of Pneumocystis jirovecii (PJ) in bronchioalveolar lavage (BAL) or sputum to diagnose infection [2,3]. In non-HIV infected individuals studies have highlighted the lack of sensitivity of microscopic methods [18]. Polymerase chain reaction (PCR) for diagnosis is more sensitive, but also detects colonised patients [19]. Differentiation of infection from colonization is possible by quantification of copy number (qPCR) [14]. In our study we used qPCR to determine PJ infection.

Exposure to steroids has been proposed as a risk factor for PJP in patients with cancer $[2,3]$. Steroids are used to treat lung cancer symptoms [20] and side-effects from radiotherapy [21,22]. All of our patients diagnosed with PJP had been treated with steroids within the 3 months prior to diagnosis. Lymphopenia has also been proposed as a risk factor $[2,23]$. Lymphocytes are relatively radiosensitive [24]. Radiotherapy for lung cancer was associated with lymphopenia in $67 \%$ of patients [25], persisting for several months. All of our patients diagnosed with PJP had lymphopenia on admission to hospital, and $13(93 \%)$ out of the 14 patients had lymphopenia lasting at least a month prior to diagnosis.

The incidence of hospital admissions for PJP in non-haematological patients rose from 0.4 per million in 2000-2005 to 1.07 per million in 2006-2010 [1]. A retrospective study [26] of 2344 patients with non-haematological cancers treated between 2008 and 2013 found $6(0.26 \%)$ patients 
diagnosed with PJP by either PCR or microscopy with staining of respiratory secretions. Patients with primary or secondary brain cancer treated with steroids had an incidence of $1.34 \%$ [27]. A study of the PCR-analysis of induced sputum in patients with acute respiratory symptoms and interstitial shadowing [28] found PJP was detected in $31 \%$ of lung cancer patients compared to $5 \%$ of patients with other solid tumours. This may indicate that lung cancer patients are at higher risk. However a retrospective review [11] between 1990 and 2010 found only $3(0.06 \%)$ cases of PJP diagnosed by microscopy out of 4879 lung cancer patients. One group [2] reported a mortality rate for PJP amongst patients with non-haematological malignancies of $31 \%$, whilst another reported a mortality rate of $17 \%$ [26]. In a retrospective review published in abstract [26] a mortality rate of $50 \%$ was recorded in 10 lung cancer patients with microbiologically confirmed PJP. We report a risk of death from PJP of $2.6 \%$ at 2 years. This seems higher than previous reports, but may reflect the rising incidence of PJP [1], or a greater exposure to risk factors such as radiotherapy-induced lymphopenia and steroid use in this patient population. Additionally it can be difficult to determine incidence rate because PJP is a rare condition requiring detection of small numbers of cases within relatively large patient populations, often requiring many years or decades of data collection. In this study, we reviewed 6 years of data, and reviewed comprehensive electronic case records.

Radiotherapy pneumonitis (RP) is part of the differential for PJP and can present with dry cough, dyspnoea and fever [21]. Radiological changes are usually confined to within the radiotherapy field, but there are reports of out-of-field and bilateral changes [22]. Out-of-field radiation pneumonitis is more rapidly progressive and carries a worse prognosis than in-field RP, with a lower response rate to steroid therapy [22]. Risk factors for RP include high lung dose [21], which can be measured by the percentage of lung receiving at least 20 Gy (V20) and pre-existing interstitial lung disease (ILD) [30]. Of the four patients who died in our series from RP, 3 had a high V20 ( $\geq 35 \%)$ and the other had a past history of ILD. Several of our patients who died from PJP were initially thought to have RP and were treated with steroids ( 2 had a V20 $\geq 35 \%$, and an additional 4 
with ILD). We recommend a low threshold for qPCR or microbiological assessment for PJP in patients admitted with suspected out-of-field or bilateral RP.

The first line prophylactic agent for PJP in HIV-infected individuals is trimethoprimsulfamethoxazole (TMP-SMX). Guidelines recommend prophylaxis for patients with cancer when 16$25 \mathrm{mg}$ of prednisolone or $\geq 4 \mathrm{mg}$ of dexamethasone are planned for $\geq 4$ weeks [31]. A study of 73 patients [4] over a 6 month period on steroids with cancer found that only $22 \%$ received prophylaxis. A higher number of patients with haematological cancer received prophylaxis than patients with solid malignancies (64\% compared to $4 \%, p<0.0001)$. Only one patient, in the group which did not receive prophylaxis, was diagnosed with PJP.

Our study has a number of potential weaknesses. Cause of death can be difficult to determine. We were assisted by the improvements in electronic recording of data since the introduction of an electronic care record. This allowed access to radiological, laboratory and clinical reports. We were able to allocate a cause of death to $99 \%$ of cases. We are unable to determine the incidence of PJP within our group or the mortality rate because we analysed cause of death. However we contend that determining the risk of death does reflect the importance of PJP in this patient population. Whilst all patients were treated in just one centre, the demographics of the cohort indicate that the results are consistent with an unselected population and are generalisable to other radiotherapy centres. Radiotherapy treatments were primarily delivered with a hypofractionated regimen (55Gy/20\#), which whilst common in the UK $[15,17]$, is not used as frequently in other countries. One patient treated with a conventionally fractionated regimen (66Gy/33\#) was diagnosed with possible PJP. We have no reason to believe that hypofractionation puts patients at higher risk of PJP. All of our patients were diagnosed with qPCR rather than microbiological staining. Whilst PCR may also detect colonisation this risk is reduced by using qPCR 
and our patients had clinically significant disease with features consistent with PJP (progressive pneumonia and consistent radiology).

\section{Conclusions}

We conclude that there is a clinically significant risk of death from PJP in patients treated with radiotherapy, which clinicians should be aware of. There is an apparent association with prior steroid use and prolonged lymphopenia with the risk of PJP. We advocate the use of chemoprophylaxis with TMP-SMX in patients receiving steroids who have had radical radiotherapy. 


\section{References}

1. Maini R, Henderson KL, Sheridan EA et al. Increasing Pneumocystis pneumonia, England, UK, 20002010. Emerg Infect Dis 2013;19(3):386-92.

2. Sepkowitz K. Pneumocystis carinii pneumonia in patients without AIDS. Clin Infect Dis 1993;17:S41622.

3. Worth L, Dooley MJ, Seymour JF et al. An analysis of the utilisation of chemoprophylaxis against Pneumocystis jirovecii pneumonia in patients with malignancy receiving corticosteroid therapy at a cancer hospital. Br J Cancer 2005;92:867-72.

4. Cancer Research UK. Cancer mortality for common cancers. Available online: http://www.cancerresearchuk.org/cancer-info/cancerstats/mortality/cancerdeaths/uk-cancermortality-statistics-for-common-cancers. Last accessed 17/04/18.

5. National Lung Cancer Audit Report 2014. Available at: http://www.hqip.org.uk/assets/NCAPOPLibrary/NCAPOP-2014-15/HSCICNLCA-2014finalinteractivereport.pdf. Last accessed 17/04/18.

6. Grutters J, Kessels A, Pijls-Johannesma $\mathrm{M}$ et al. Comparison of the effectiveness of radiotherapy with photons, protons and carbon-ions for non-small cell lung cancer: a meta-analysis. Rad Oncol 2010;95:32-40.

7. Saunders M, Dische S, Barrett A et al. Continuous, hyperfractionated, accelerated radiotherapy (CHART) versus conventional radiotherapy in non-small cell lung cancer: mature data from the randomised multicentre trial. Rad Oncol 1999;59:137-48.

8. Maugren A, Le Pechoux C, Saunders MI et al. Hyperfractionated or accelerated radiotherapy in lung cancer: an individual patient data meta-analysis. JCO 2012;30(22):2788-97.

9. O'Rourke $\mathrm{N}$, Roque I, Figuls $\mathrm{M}$ et al. Concurrent chemo-radiotherapy in non-small cell lung cancer. Cochrane Database Syst Rev 2010;16(6).

10. Filatre $P$, Decaux $O$, Jorneau $S$ et al. Incidence of Pneumocystis jiroveci pneumonia among groups at risk in HIV-negative patients. Am J Med 2014;127(12):1242.e11-7.

11. NICE. Lung cancer (CG121). The diagnosis and treatment of lung cancer (update of NICE clinical guideline 24. Available online: http://guidance.nice.org.uk/CG121. Last accessed 17/04/18.

12. American Joint Committee on Cancer Staging. Lung cancer $7^{\text {th }}$ edition. Available online: https://cancerstaging.org/references-tools/deskreferences/Pages/AJCC-7th-Ed-Cancer-StagingManual.aspx. Last accessed 17/04/18.

13. Maillet $M$, Maubon D, Brion JP et al. Pneumocystis jirovecii (Pj) quantitative PCR to differentiate Pj pneumonia from Pj colonization in immunocompromised patients. Eur J Clin Microbiol Infect Dis 2014;33(3):331-6.

14. McAleese J, Baluch S, Drinkwater K. The quality of curative-intent radiotherapy for non-small cell lung cancer in the UK. Clin Oncol (R Coll Radiol) 2015;17:498-504.

15. McAleese J, Cullerton G, Henry A et al. Survival for patients following radical radiotherapy in the Northern Ireland cancer network in comparison to a large European cohort. Lung Cancer 2017;103:S58-9.

16. Din OS, Harden SV, Hudson E et al. Accelerated hypofractionated radiotherapy for non-small-cell lung cancer: results from 4 UK centres. Radiother Oncol 2013;109(1):8e12.

17. Flori $P$, Bellete B, Durand F et al Comparison between real-time PCR, conventional PCR and different staining techniques for diagnosing Pneumocystis jiroveci pneumonia from bronchoalveolar lavage specimens. J Med Microbiol 2004;53:603-7.

18. Robert-Gangneux $\mathrm{F}$, Belaz $\mathrm{S}$, Revest $\mathrm{M}$ et al. Diagnosis of pneumocystis jirovecii pneumonia in immunocompromised patients by real-time PCR: a 4 year prospective study. J Clin Microbiol 2014;52(9):3370-6.

19. Yennurajalingam S, Frisbee-Hume S, Palmer JL et al. Reduction of cancer-related fatigue with dexamethasone: a double-blind, randomized, placebo-controlled trial in patients with advanced cancer. J Clin Oncol 2013;31(25):3076-82 
20. Mehta V. Radiation pneumonitis and pulmonary fibrosis in non-small-cell lung cancer: pulmonary function, predication, and prevention. Int J Oncol Biol Phys 2005;63(1):5-24.

21. Wang JY, Chen KY, Wang JT et al. Outcome and prognostic factors for patients with non-small cell lung cancer and severe radiation pneumonitis. Int J Oncol Biol Phys 2002;54(3):735-41.

22. Sen RP, Walsh TE, Fisher W, et al. Pulmonary complications of combination therapy with cyclophosphamide and prednisolone. Chest 1991;99:143-6.

23. Nakamura N, Kusunoki Y, Akiyama M. Radiosensitivity of CD4 or CD8 positive human T-Lymphocytes by an in vitro colony formation assay. Rad Res 1990;123:224-7.

24. Campian J, Ye X, Brock $M$ et al. Treatment-related lymphopenia in patients with stage III non-small cell lung cancer. Cancer Invest 2013;31(3):183-8.

25. Koyama T, Kasahara Y, Shigematsu Y et al. Pneumocystis jirovecii pneumonia (PJP) in non-HIV infected patients with solid tumor. Ann Oncol 2014;25(suppl 5):v51-v52.

26. Sepkowitz KA, Brown AE, Telzak EE et al. Pneumocystis carinii pneumonia among patients without AIDS at a cancer hospital. JAMA 1992;267:832-7.

27. Mori $\mathrm{H}$, Ohno $\mathrm{Y}$, Ito $\mathrm{F}$ et al. Polymerase chain reaction positivity of pneumocystis jirovecii during primary lung cancer treatment. Jpn J Clin Onc 2010;40(7):658-62.

28. Chavalertsakul N, Lwin Z, Hay K et al. Pneumocystis pneumonia (PJP) in lung cancer patients. AsiaPac J Clin Oncol 2016;12(Suppl_5):55-168.

29. Ueki N, Matsuo Y, Togashi $Y$ et al. Impact of pretreatment interstitial lung disease on radiation pneumonitis and survival after stereotactic body radiation therapy for lung cancer. J Thorac Oncol 2015;10(1):116-25.

30. Cooley L, Dendle C, Wolf J et al. Consensus guidelines for diagnosis, prophylaxis and management of pneumocystis jirovecii pneumonia in patients with haematological and solid malignancies, 2014. Int Med Journal 2014;44:1350-63. 